\title{
Encountering bloody others in mined reality
}

\author{
Nika Mahničč, \\ Received: 13 November 2017 / Accepted: 4 January 2018 / Published online: 17 January 2018 \\ (c) The Author(s) 2018. This article is an open access publication
}

\begin{abstract}
This article explores interpersonal and human-computer interaction in the era of big data through the lens of Martin Buber's relational ethics. Doing theory otherwise, it analyses the importance of other voices and speech through the case of digital assistants, questioning the implications of naming them 'companions'. Following recent proposals to ascribe legal subjectivity to synthetic agents, the article explores the effects on agency, interaction with flesh-and-blood others and democracy in an attention economy enmeshed with technologies of behavioural manipulation powered by users' utterances that enable novel forms of social control by owners of the means of communication.
\end{abstract}

Keywords Reality mining $\cdot$ Digital assistants $\cdot$ Digital companions $\cdot$ Big data $\cdot$ Attention economy $\cdot$ Computational propaganda

\section{Introduction}

It feels inappropriate to write about the importance of embracing speech and face-to-face interaction as a mode of revealing and making ourselves importantly vulnerable. I believe the interpenetration of interpersonal communication with digital devices, a quotidian experience, despite enabling us to maintain contacts with others beyond our reach, leaves out-following Martin Buber's relational ethics-the most important elements of interpersonal relationships, eye contact, voice and bodily gestures. Moreover, the prevalence of digital communication leaves out smell and the other magical spells of relationships. In this article, I invite you to follow my inter-trans-un-disciplined narrative that will hopefully make you think, and then feel, twice before returning Home to your online, supposedly organic community.

I return to Martin Buber's ethics in the era of big data, to rethink the spaces that enable and disable relations to fleshand-blood others whom I christen bloody others. Digital economy complicates this process, as bloody others often voluntarily or unintentionally, talk or listen to their digital assistants, bots inhabiting online spaces, or digital doubles of their friends and 'friends'. This article seeks to provide

\footnotetext{
Nika Mahnič

nmahnich@gmail.com

King's College London, London, UK

Danes je nov dan, Ljubljana, Slovenia
}

a framework delineating the stakes of these developments for what is left of democracy: I focus on the relation of the personal to the political, concentrating on voice and speech as embodiments of unique expression that extend towards others in a manner that is often, in thought-based philosophy, left out or deemed less important.

\section{I Thou You}

"True love is a lack of desire to check one's smartphone in another's presence." (Alain de Botton in Turkle 2015: 177)

Philosopher Martin Buber, whose I and Thou illuminates this edition of $A I \&$ Society, represents an important take on the paradigm(s) of social robotics, a field often celebrating the relational promises of the new tools that could repair, and cheapen, our "broken" sociabilities and sensibilities.

My reading of Buber in a language that I rarely feel but predominately think in, English, is at least doubly "flawed", as I and Thou was never translated into my mother tongue. For Buber, however, the heart of the matter is not solely about understanding, but feeling-it is about compassion and not cold-hearted, rational perception or analysis.

Contradictorily, presence is a phenomenon that cannot be sufficiently understood by reading dead words, conversing with theoria. The execution would be much better if I wrote in the tongue that calls my mother, Slovenian-the language, 
in which degrees of separation between people in conversation are lessened by addressing you, addressing us, in dual, the dual verbal form. "Midve želiva" in English would be "We want," but in Slovenian "Us two women want." Unfortunately, this linguistic peculiarity is slowly disappearing from spoken Slovenian, and in line with Buber's linkages between ways of addressing and community-building, one could draw a parallel with increasing individualization or the changing nature of intimacy, in this case perhaps more pertinent as a characteristic of post-socialist countries.

In the words of Walter Kaufmann writing on I and Thou (in Buber 1970: 38): "This book will survive the death of theology, for it appeals to that religiousness which finds no home in organized religion, and it speaks to those whose primary concern is not at all with religion but rather with social change." Following my academic upbringing (Šterk 2003), I believe that the train of thought, intentions behind ideas, as well as their applicability, can be understood better if we turn to the author's biography. As we read from one of Buber's biographers, Maurice Friedman (1996: 4), when Buber was 4 years old, his mother left home. He went to live with his grandparents who spoke little of her disappearance, and little Martin expected his mother to return. In one reported conversation, a childhood friend told him she will probably not. Buber later described how it felt:

"I cherished no doubt the truth of her words; they cleaved to my heart, and every year they cleaved deeper and deeper. After ten years, I came to understand it as concerning not only me but all persons and after another ten years I coined the term 'Vergegnung'

- 'mismeeting'." (Buber in Friedman 1996:4)

His mother's absence shaped Buber's theory of presence: presentness. Buber (1961: 33), however, dismissed the importance of biographical information for pure understanding of the author's work. He advised instead to delve into works of art in the same manner as we address others-nature, surroundings, God-as something special; as whole-openly and without preconceptions of the object/ subject/matter approached. Writing on Buber's relational philosophy, specifically his philosophical anthropology, Friedman (1996: 16) recognizes movements of distancing and relating, and the dual human relation(s) of 'I-Thou' and 'I-It'.

'I-I', 'I-It', It-It', 'We-We', 'Us-Them', 'I-You' and 'I-Thou' are, basic words that form-when spoken-a mode of existence (Buber 1970: 53-58). These basic words are tied to different manners of relating. 'Thou', the oldfashioned way of saying 'You', writes Kaufmann (in Buber 1970: 15), is the word of preachers, anticlerical romantic poets, Shakespeare and the English Bible. Already in 1970, 47 years after $I$ and Thou was first published, Kaufmann observed the absence of 'Thou' in conversational, informal and spontaneous relationships between humans. And in 2015, when Sherry Turkle's Reclaiming Conversation was published, her fieldwork demonstrated that focused faceto-face conversations (in the manner similar to Buberian 'I-Thou' relations) are rapidly disappearing.

As Turkle warns (2015), communicating and conversing through digital technologies disengage us in important ways. Interestingly, constant connectedness erases our capacity for productive solitude, solitude as a prerequisite for seeing others as separate and independent, which is the soil for growing empathy. Moreover, our relating to phones and other gadgets, apart from its effects on empathy, has also wider politico-economical consequences.

\section{More than words}

Uniqueness without reciprocal communicative action in a shared space, writes Adriana Cavarero (2005: 204), is an ontological given that cannot make itself political. This view contrasts with Pettiman's (2006: 203) self-labelled blunt claim that ontology is intrinsically political, and materially effective, as it "addresses who and what exists, under what regimes of meaning, and for whom." Contemporary social and cultural theory, as well as popular culture, is full of promises and exploratory, even emancipatory potentials of posthumanist, transhumanist, or other theoretical orientations, such as object-oriented ontology, that enable thinkers to transcend the limits of anthropocentrism embedded in humanities. For this matter, in the manner of rejuvenating conversations with bloody others, reconceptualising the political, I conversed with some other thinkers, ones I consider less pessimistic and perhaps less pure or exact, at the expense of pouring more heart into their embodied theories that counter the traditional thought-based philosophy.

As you will read, I often engage with female thinkers, which is, unfortunately, a political act. What makes me pursue this tactic are often writings by male theorists whom I respect in many instances and sentences, but we often clash on the slippery terrain where they proclaim the position of universality that they write from and strive towards. Often this is combined with a disregard of identity politics pursued by Others. I cannot but quote the incredibly lucid Pettiman, who despite his deep understanding of the making of communities, love and other technologies that make up our lives, discredits female self-empowerment for its incapacity to transcend the "individualist-isolationist economy of divide and conquer." His proposal "the only way to defy the sinister logic of "Every man for himself" is to erase the category of "man" which comprises its very foundation" (Pettiman 2006: 203) reminds me of (transhumanist) proposals for 
overcoming humanness, often proclaimed by white, straight and Western males.

In Between You and I: Dialogical Phenomenology, Beata Stawarska (2009: ix) studies the egocentric tradition in classical phenomenology, considering the way in which it researches the communicative structure of experience, as insufficient. She is thus suggesting a turn away from egocentrism, towards a polycentric view on communication or conversation, and focusing on 'I-You' connectedness, which is studied best within living speech. Moreover, she emphasizes the workings of "the mentalistic construction of thoughtbased philosophy, traditionally practiced by those privileged enough not to fear for their rights." (ibid.) Similar concerns are raised by Cavarero (2005: 9), saying that the philosophical tradition often ignores uniqueness. She focuses on its vocal communicability, and the act of speaking as inherently relational (ibid., 13). That is in line with Buber's focus on the importance of reciprocity in relations, and the voice, being an utterance that in most cases "demands" a response, presents itself as a very good object to think with and about.

To better understand bloody others, it is productive to turn our gaze, or ears, towards gadgets, robots or as they are increasingly being called, digital 'companions'.

\section{Attention! Economy}

It is particularly machines with voices that have the power to make us feel understood (Turkle 2015: 341), which makes them even more convincing for retaining people on platforms and devices, which is the ethos of attention economy. In the digital economy, states The Onlife Initiative (2015: 12 ), attention is approached as a commodity to be exchanged on the market place. In his TED talk, Tristan Harris (2017), former design ethicist at Google, voices a concern about the power that Facebook has over their 2 billion users' lives-in his words, it has more influence on people's daily thoughts and beliefs than any religion or government, because with every click, it learns what will keep you there longer and make you come back. IT companies working in the attention economy provide (social) experiences that strive towards keeping people on their platforms. How this is in contrast with the 'I-Thou' relation, is best exemplified by Buber, who wrote in I and Thou (1970: 60), "Experience is remoteness from You." Experiences on digital platforms are ever more immersive and addictive, as the main business of corporations, such as Google and Facebook, is to capture and retain people's attention. As the companies profit from our attention, they design their products in a manner that glue us to our gadgets and keep us at distance from bloody others.

Digital companions, writes Marc Prosser for SingularityHub, signify a new phase in human-computer interaction. Despite the obvious techno-optimism of writers associated with the singularity movement, I consider such sources a good indicator of the trends being hyped. "While American internet giants are developing speakers, Japanese companies are working on robots and holograms." (Prosser 2017) Despite those differences, their common goal is, he writes, to devise platforms that will serve as the remote controls for Internet of Things systems. From his observations of commercial trends, there seems to be a growing consensus, explicated by Yorick Wilks (2006) that language and speech technologies, embodied in artificial companions, might become the primary way of using the internet in the years to come. As he puts it: "It is above all this lack of conversation with the Internet that the Companion seeks to remedy." (ibid.) But what I am concerned with is the lack of conversation within and in-between humans, not the lack of interaction between humans and the internet.

\section{More than voice}

Instrumental, I-It relationships in Buberian terms bear an uncanny resemblance to the functioning of digital assistants, increasingly named digital companions. Kaufmann, departing from Buber, describes I-It relationships: "Innumerable are the ways in which I treat You as a means. I ask your help, I ask for information, I may buy from you or buy what you have made, and you sometimes dispel my loneliness" (Kaufmann in Buber 1970: 16-17). One senses a parallel with the way in which this usability is promoted in the case of digital assistants. Apple's first TV advertisement for Siri, writes Turkle (2015: 339), introduced her as a companion, not solely as an assistant or a convenient tool for acquiring information. The advertisement involved a cast of famous actors, such as Samuel L. Jackson, Zooey Deschanel and John Malkovich, and Siri was cast in the role of confidante. The first machine to imitate human voice, writes Mladen Dolar (2006: 8-9), was constructed by Wolfgang von Kempelen. Die Sprach Machine spoke French, Italian and Latin, and from some examples of vocabulary it follows that its speech had two main functions: declaring love and praising the ruler. "The minimal vocabulary has the purpose of displaying the posture of emotion; the machine's voice is used to declare its submission, be it to the abstract beloved or to the actual ruler."

In Philosophy of dialogue and feminist psychology, Rose Graf-Taylor (1996: 328) contraposes 'I-Thou' and personal connectedness to 'I-It' and service-oriented connectedness. She writes that 'I-It' relationships enhance knowledge and skills, whereas 'I-Thou' relationships are a predisposition of human knowing and integrity: "growth of a person in her wholeness takes place only in personal relation, while I-It is the attitude which takes care of physical survival and comfort." (ibid.) In this light, 
presenting digital assistants as companions reveals the ethics of designers, in line with an egocentric view on interpersonal, or in this case, human-computer interaction. Moreover, they reveal the gendered nature, or the culture of making robots-digital assistants are predominately female, which is in line with the servile role often expected from females in different, from care to other work, assistive relationships.

For Buber, "/b/eing I and saying I are the same." (Buber 1970: 54) and "relation is reciprocity." (ibid., 58) But the basic words are often not spoken, and even when they are, they are often not heard by an ear: years of researching people's relationships to and with (digital) technology made Turkle emphasize the prevalence of the feeling of not being listened to (2015: 357). And if you can recall the discourse around political campaigns and people's disappointment with the representative democratic systems, the concern and disagreement are often connected to the feeling that politicians do not listen to or hear the citizens' concerns.

Voice and speech have a very special dimension-in sacred and secular situations we encounter the performative dimension of speech when it conceives a specific (codified) act. Prayers, for example, are uttered viva voce (Dolar 2006: 107 ) - by the voice, and "court proceedings have very strict rules about the parts of the process and the depositions that have to be made by voice." (ibid., 108) On a semantic level, speech, writes Stawarska (2009: 108), is an ability and a political right, which can be granted or not. Women, for example, are being denied a representative function in Catholic clergy, and in Islam, "a woman attempting to employ the talak illocution to divorce her husband (by saying "Divorced, divorced, divorced") necessarily fails because she is not a man." (ibid.) On this point, I would like to remind you of the importance of ontology and the ways in which philosophy still retains power, namely in the sphere of its instrumentalisation for political purposes. Theorising about relationships with objects, perceiving oneselves as cyborgs or machines, questioning humanity to the extreme-produces effects on the power and rights of machines versus humans.

When we come to the point when European Parliament and Commission consider giving legal, electronic personhood, and therefore, rights to robots and AI, and Sophia the robot suddenly has more rights than women in Saudi Arabia (Vincent 2017), it is time for upsurge because it seems that the ones with voice in political terms are increasingly corporations and commodities (robots and AI), not people. Joanna Bryson and others (2017) point out that in the case of giving legal subjectivity to robots and AI, humans' rights are being endangered as establishing electronic personhood might seriously affect the already weak respect for human rights, in ways previously unimaginable. A similar development, the authors write, might be corporations granted legal subjectivity, which enabled them to become the engines of economic progress - and, I might add, human exploitation.

In the era when the power balance between corporations, political actors and regulators is shifting, as IT companies provide —or do not provide — data to governments, the claim that politicians are not listening to citizens takes on a fresh meaning. I argue that another sovereign, or another cohort of sovereign corporations, have enough power to prevent political actors exercising their rights. According to Giorgio Agamben (1998: 15), a sovereign is an entity that is simultaneously inside and outside the juridical order. This new sovereign is named by Shoshana Zuboff the 'Big Other', and is importantly tied to the everyday experiences of datafied citizens. 'Big Other' is a novel expression of power vested in the new model of information capitalism whose foundational component is big data. According to Zuboff (2015: 79), big data "are constituted by capturing small data from individuals' computer-mediated actions and utterances in their pursuit of effective life." In this system, the main aim of harvesting data is predicting and modifying human behaviour, which is being done by purposefully organizing perception (ibid.: 75-7). She named this new system surveillance capitalism: it was constituted in the last decade, importantly through technologies developed by Google, and it transformed social relations and politics (ibid., 76).

\section{Conversational spy agents}

Buber (1970: 168) writes that in every new age, doom is more oppressive, "the theophany comes ever closer, it comes ever closer to the sphere between beings-comes closer to the realm that hides in our midst, in the between." The inbetween became digitalized, datafied and commodified, as well as subject to incessant surveillance. Turkle (2015: 50) writes that digital communication expedites surveillance. The lines between private communications and routine surveillance-as well as between private communications repackaged as commodities-have become blurred. Zuboff describes the functioning of this ubiquitous networked regime, surveillance capitalism, as one that "records, modifies, and commodifies everyday experience from toasters to bodies, communication to thought, all with a view to establishing new pathways to monetization and profit." (Zuboff 2015: 81)

Reading this, it is obvious that it is not solely about manipulating the spaces we enter through digital devices to shop or communicate, but the spaces we inhabit in general-those spaces that once constituted the in-betweenthat Buber and Stawarska deem so important for breeding 'I-Thou' relationships. Zuboff (2015: 78) writes that apart from computer-mediated electronic transactions, an increasing amount of data fuelling the economy comes from sensors 
embedded in objects, bodies and places. Andrejevic and Burdon (2015) name it "sensor society." An important component of this system-to utilise Zuboff's term surveillance capitalism-are smart devices for the home, for example Cortana (Microsoft) and Echo (Amazon), which were popular amongst last year's Christmas presents.

Reading Google's Chief Economist Hal Varian's revelations about the technologies they employ and experiments they pursue, Zuboff emphasizes their understanding that "habitats inside and outside the human body" produce "opportunities for observation, interpretation, communication, influence, prediction, and ultimately modification of the totality of action." (2015: 82) Varian (2013: 4) tells the story about Google co-founder Larry Page saying that instead of the user asking Google questions, Google should already know their desires. Varian excitedly continues that this has been made possible by Google Now. These developments, however, have been made possible by the fact that, quoting Varian, "when you access Google you are in dozens of experiments." (ibid.:7)

The various and popular "conversation avoidance mechanisms" (Miller 2006: 297), importantly our cell phones, change the nature of our interaction and consumption, the two domains that are becoming increasingly interrelated. Interrelated to such an extent that they ever more aggressively eliminate the public sphere, the backbone of our democracies. As reported by Alex Hern for The Guardian (2017), one of the latest experiments by Facebook restructured the News Feed in seven countries, eliminating professional news media at the expense of paid adverts and personal posts.

Zuboff claims that in the context of the 'Big Other', power as ownership of the means of production transforms into power that comes with owning the means of behavioural modification (Zuboff 2015: 82), of power by those who own the means of communication and profit from the possession by media. "Predictive analytics, reality mining, patterns-oflife analysis" (ibid: 80) thrive in the digital everydayness and in the feedback loop transform it for the aims of the ones who do not use these platforms for "free", such as us, digital paupers.

\section{Responsibility in mined in-betweeness}

Zuboff's notion of surveillance capitalism can be paired with Turkle (2015: 300) and her fieldwork observations that led her into analysing the so-called catastrophe culture, where the nature of communication, as well as political action, changes. Attention is short-term and despite feeling part of a series of catastrophe events, political "agitation is channelled on to donating money and affiliating with a website" (ibid.) Moreover, bad news and shiny objects on social media bring more clicks, more profit-but that rarely transforms into effective political action. Quite the contrary: clicktivism often enables no more than a new form of political propaganda that addresses you as a particular user with particular vulnerabilities, interests and needs, and thus makes you malleable to various agents competing for your attention.

Hannah Arendt's claim "Wherever the relevance of speech is at stake, matters become political by definition, for speech is what makes man a political being." (Arendt 1958: 4) must be taken seriously, especially in an era where history is being rewritten by Google search engines and important (historical) events are chosen by Safety Check. For these reasons, I believe it is important not to be ahistorical and pretend our era is more posthuman than the one where eugenics and other race pseudosciences separated humans from subhumans.

Online, we are surrounded by "botnets, bot armies, sockpuppets, fake accounts, sybils, automated trolls, influence networks" (DiResta et al.: 2017) that compete for our own and our friends' attention toward certain topics. In 2015, Zeifman (in Wooley and Howard 2016: 4884) wrote that bots make up almost $50 \%$ of all online traffic and represent a significant number of active users on social media. Politibots or political bots are the "algorithms that operate over social media, written to learn from and mimic real people so as to manipulate public opinion across a diverse range of social media and device networks." (ibid.: 4885)

Computational propaganda is having an ever larger hold over our lives, not solely on elections in representative democracies. That is one of the reasons I consider theorists writing about the emancipatory aspects of blurring the line between humans and robots, because we are all cyborgs, irresponsible. I deem direct political action more important than theoretical excursions designed to rejuvenate identity politics, often by despising them at the same time by expressing the need to get rid of the boundaries that separate bloody from synthetic others. I deem Donna Haraway's claim "The cyborg is our ontology; it gives us our politics" (Haraway 2004: 8), in the era when politibots traverse our (cyber)realities, a sentence of big significance, as it demonstrates how quickly concepts can get a life of their own. Is Haraway satisfied with the politics the cyborg metaphor helps enable?

In Dialogue, one of the essays in his Between Man and Man, Buber focuses on the everyday, which is also how he conceives of the religious dimension-not as something extraordinary.

"I know no fullness but each mortal hour's fullness of claim and responsibility. Though far from being equal to it, yet I know that in the claim I am claimed and may respond in responsibility, and know who speaks and demands a response.” (Buber 1961: 31) 
But on platforms and spaces that demand our attention and data in ways that would seem alien in the time of Buber, human agency takes on a different, weakened functioning. Voice, writes Dolar (2006: 95), is fundamentally tied to the notion of responsibility: "it is a response to a voice." How do we conceive of responsibility in an era when we are encouraged to talk to digital companions that are soon perhaps going to get legal subjectivity? Or when we do not know whether it is a bot, or not? We cannot say, unlike Buber, that we know who speaks and demands our response.

Zuboff (2015: 76) points towards "everydayness as a commercialization strategy" that ever more efficiently subsumes humans and their free (?) will under the logic of profit maximization enabled by automated attention manipulation. It profits from instrumental relationships of users with other people, other bots and other products on platforms. Having a voice on social media, often being proposed as emancipatory, is in fact just another way of making profit for governmental and corporate propaganda, and IT companies living off data harvesting. And even voice, the marker of uniqueness, is being synthesized and subsumed under the logic of profit maximization through the capture of voice communications-your interactions with digital assistants/companions, as well as bloody others inhabiting the datafied spaces.

\section{Resisting the datafied encounter}

"Genuine responsibility exists only where there is real responding." (Buber 1961: 34)

Sherry Turkle (2015: 16-7), one of the most famous converts from the wonders to the horrors of digitally mediated building of ourselves, describes our "voyage of forgetting": first, speaking through machines made us forget about the importance of face-to-face conversations, and second, speaking to machines leads us even further from each other. Turkle's (ibid: 140) field work in the United States indicates that groups of young friends spend time in physical proximity, but when they meet, the main purpose of meeting is not talk, but physical closeness, sometimes combined with a layer of digital communication-even when friends are present in the same room, sometimes they speak only through digital devices.

People are unpredictable and "can seem difficult to contend with after one has spent a stretch in simulation." (Turkle 2015: 7) Her fieldwork conducted between 2008 and 2010 with high school and college students showed that interviewees perceive improvised real-time conversation as something that makes them avoidably vulnerable (ibid.: 143). As one of her other fieldwork studies show (ibid: 154), in 2008, members of one group of friends she studied had to apologize to each other for being inattentive whilst being physically close to others due to their use of cell phones. Just several years later, they said, that nicety became unimportant.

Kaufmann considered (in Buber 1970: 12) the ones who perceive a large part of humanity operating by the principles of the instrumental 'I-It', instead of 'I-You' or 'I-Thou' relations, as consenting to demonology. However, I argue that in the era I attempt to analyse in this article, not consenting to demonology leaves our critique fleeting and the Faustian pact intact. The demons that convinced me into thinking that, in contrast to my previous explorations, cyberspace might be one of the least suitable spaces for the practice of democracy, must be named. As Facebook counts more than two billion active Facebook users, we might as well state that a large part of humanity subscribes, at least in part, to an instrumental and ever more manipulated manner of interpersonal interaction. As Wooley and Howard (2016: 4887) put it: "algorithms govern the burgeoning communications between us. Such algorithms mediate almost all interaction and content that we do not experience directly, face-to-face and in person. We find people communicating, sometimes unawares, with automated scripts."

In The Human Condition, Arendt states "It seems to be in the nature of the relationship between the public and the private realms that the final stage of the disappearance of the public realm should be accompanied by the threatened liquidation of the private realm as well." (1958: 55) What happens to the public and private realms in the era when Facebook's CEO questions the relevance of privacy remains open for theoretical explorations and even more urgently, political action.

Franzen (2008) and Turkle (2015) write that on September 11, 2001, we entered the cell phone age, at least in the US. Turkle associates cell phones with catastrophe culture, imbued with emergencies - as on that Day schoolchildren were in basement shelters without phones, "their parents vowed that 'never again' would they be so disconnected." What happened, at least according to fieldwork in the US, is that always-connected children talk of their everyday lives as composed of emergencies, which in Turkle's words makes them develop a fretful self (2015: 299). In a book structured as a conversation with David Lyon Liquid Surveillance, Bauman and Lyon (2013: 101) writes that the obsession with contemporary security renders forms of insecurity-in people who are supposed to be protected by them. Moreover, he also points out the significance of the era after $9 / 11$, but states that this event made obvious the risk management practices present for several decades before.

Those very practices of risk and attention management are something that makes our eyes and increasingly, ears, stick to our phones and other devices, providing more behavioural data for engaging us with our phones. As Turkle emphasizes, we need to reclaim attention if we want to reclaim conversation (2015: 42). Reclaiming it, however, 
is a difficult task, as attention is what rich corporations employing very intelligent designers of immersive apps are manipulating - for a smoother and ever smarter consumerist propaganda. As Wooley and Howard (2016: 4886) explain it, the autonomous agents who inhabit the spaces of our interactions are armed with big data about our online behaviour, and engage us in ideological projects-by those who can afford to steer attention.

In Infinite Distraction, Pettiman (2016: 13) postulates that television, at the time of Jean Baudrillard writing his critique of the masses being the "silent majority" watching television, could not "track your eyeball movements, eavesdrop on your conversations, and invite you to purchase product placements in real time." (ibid.) Another thing that changed is the way in which everyday digital experience fuels our economy and is commodified more than ever. If we once celebrated the emergence of the prosumer, we now perhaps find ourselves at the point where the benefits that once outweighed the losses of information economy increasingly meddle with the-if I dare using the archaic and coopted by digital marketing word—organic functioning of our digital(ised) interactions.

\section{Conclusion}

Can we conceive of digitally mediated conversation or communication with artificial agents as real responding in Buber's terms, taking a person as they are, without preconceptions? I argue this is not the case: bots, online friends with their dispersed attention and artificial agents deemed companions cannot respond in a way that would satisfy Buber. And to reclaim communication, we must make radical steps back-Buber's 'I-Thou' relation presents itself as a viable relation-help guide to discovering an interrelated self in the era of egocentric, irresponsible individualism.

Ideas traversing this text are in important aspects an antipode to the article I wrote in 2014 for the journal Teorija in praksa, titled Gamification of politics: Start a new game! Back then, I believed in the promises of human-computer interaction techniques, namely gamification, for effectively mobilising people around topics and ideologies, as well as mobilising physical neighbours, getting them more involved in the political. Even though I was never a gamer, I held a firm belief that serious games and virtual environments present a cure for political alienation, especially for the youth. Despite some panopticon-inspired pessimism of the text, I imagined the benefits of free, utopian spaces of the ever more connected digital world. I wrote (2014: 155) that we need to believe that the body, because of its discriminatory aspects, is useless for political action, and that people's deeds should be more important than external signs. Drawing from Diana Saco (2002: 205), I was led into thinking that bodily signifiers in face-to-face interactions play a big part in systematic exclusions that would fall by the wayside in the event we displace the public space and replace it with cyberspace.

I want to make this the main proposition of this article, that it is important to inquire into the nature of the black boxes and understand more about the functioning of digital industries, as well as the ways in which they interfere with our everyday. That is in line with Zuboff's (2015: 83) claims that it is users' ignorance that drives surveillance capitalism, not consent. Only when we are able to establish informed consent can we assure that users agree on the functioning of the 'Big Other' and decide whether they accept the terms that condition them. As Pettiman puts it: "we are slaves to the notion that we are masters." (2006: 171) We need researchers, artists, thinkers, journalists, computer scientists, everyone working on that topic, not to be silent about the behavioural engineering we are being infused with. As The Onlife Initiative wrote in the Onlife Manifesto (2015: 12-13), societies must protect, nurture and cherish attentional capabilities of humans, being the "inherent element of the relational self for the role it plays in the development of language, empathy, and collaboration." (ibid.: 13)

As you may have noticed, in the article I jump from instrumental usage of digital companions to conversations with our digitally doubled friends, or bloody others. I try to engage with the critique of the cyborg metaphor, by showing the dark sides of the blurring of the various sphere spaces, that work in favour of the datafied economy, where boundaries lose their impact, as "everything" is datafied, and $n=$ all. I see $n=$ all, the mantra of big data, as a totalizing, I dare say, a totalitarian notion that must be explored further if we want to retain critical spaces that allow incommensurability of lifeworlds and keep ambivalence alive and kicking. I hope, dear reader, that I managed to gently and consensually steer your attention.

Open Access This article is distributed under the terms of the Creative Commons Attribution 4.0 International License (http://creativecommons.org/licenses/by/4.0/), which permits unrestricted use, distribution, and reproduction in any medium, provided you give appropriate credit to the original author(s) and the source, provide a link to the Creative Commons license, and indicate if changes were made.

\section{References}

Agamben G (1998) Homo Sacer: Sovereign Power and Bare Life. Stanford University Press, Redwood City

Andrejevic M, Burdon M (2015) Defining the Sensor Society. Television New Media 16(1):19-36

Arendt H (1958) The human condition. Doubleday anchor books, University of Chicago Press: New York City

Bauman Z, Lyon D (2013) Liquid surveillance. Polity, Cambridge and Malden 
Bryson JJ, Diamantis ME, Grant, T.D. Of, for, and by the people: the legal lacuna of synthetic persons. Artif Intell Law (2017). https:// doi.org/10.1007/s10506-017-9214-9

Buber M (1961) Between man and man. Collins, London

Buber M (1970) I and Thou. T\&T Clark, Edinburgh

Cavarero A (2005) For more than one voice: toward a philosophy of vocal expression. Stanford University Press, Redwood City

DiResta R and others (2017) The Bots That Are Changing Politics. VICE Motherboard, Thursday 2 November. https://motherboard. vice.com/en_us/article/mb37k4/twitter-facebook-google-botsmisinformation-changing-politics. Accessed 13 Nov 2017

Dolar M (2006) A voice and nothing more. The MIT Press, Cambridge and London

Franzen J (2008) "I Just Called to Say I Love You" Cell phones, sentimentality, and the decline of public space. MIT Technology Review, Tuesday 19 August. https://www.technologyreview.com/ s/410623/i-just-called-to-say-i-love-you/. Accessed 13 Nov 2017

Friedman M (1996) Martin Buber's "Narrow Ridge" and the human sciences. In: Friedman M (ed) Martin Buber and the Human Sciences. State University of New York Press, New York, pp 3-25

Graf-Taylor R (1996) Philosophy of dialogue and feminist psychology. In: Friedman M (ed) Martin Buber and the Human Sciences. State University of New York Press, New York, pp 327-334

Haraway D (2004) The haraway reader. Taylor \& Francis Group UK

Harris T (2017) How a handful of tech companies control billions of minds every day. TED. https://www.youtube.com/ watch? $\mathrm{v}=\mathrm{C} 74 \mathrm{amJRp} 730$. Accessed 13 Nov 2017

Hern A (2017) 'Downright Orwellian': journalists decry Facebook experiment's impact on democracy. The Guardian, Wednesday 25 October. https://www.theguardian.com/technology/2017/oct/25/ facebook-orwellian-journalists-democracy-guatemala-slovakia. Accessed 13 Nov 2017

Howard PN, Wooley SC (2016) Political Communication, Computational Propaganda, and Autonomous Agents. Int J Commun 10: 4882-4890. http://comprop.oii.ox.ac.uk/wp-content/uploads/ sites/89/2016/10/WoolleyHoward.pdf. Accessed 13 Nov 2017

London and Glasgow: Collins Clear-Type Press

Mahnič N (2014) Gamification of politics: Start a new game! Teorija in praksa 51 (1): 143-161. https://www.fdv.uni-lj.si/docs/ default-source/tip/tip_1_2014_mahnic.pdf?sfvrsn=0. Accessed 13 Nov 2017

Miller S (2006) Conversation: a history of a declining art. Yale University Press, Bingamthon

Pettiman D (2006) Love and other technologies. Retrofitting eros for the information age. Fordham University Press, New York City

Pettiman D (2016) Infinite distraction. Polity Press, Cambridge and Malden

Prosser M (2017) Better Than Smart Speakers? Japan is Making Robot and Hologram Companions. Singularity Hub, Wednesday 18 October. https://singularityhub.com/2017/10/18/better-thansmart-speakers-japan-is-making-robot-and-hologram-companions/. Accessed 13 Nov 2017

Saco D (2002) Cybering democracy: public space and the internet. University of Minnesota Press, Minneapolis

Stawarska B (2009) Between you and I: dialogical phenomenology. Ohio University Press, Athens

Šterk K (2003) Ali moramo poznati biografijo, da bi razumeli teorijo: socialnoantropološki uvod in psihoanalitski primer Freudove teorije zapeljevanja. Časopis za kritiko znanosti, domišljijo in novo antropologijo. 31 (211): 209-225

The Onlife Initiative (2015) The onlife manifesto. In: Floridi, L (ed) The onlife manifesto: being human in a hyperconnected era. https://link.springer.com/book/10.1007\%2F978-3-319-04093-6. Accessed 13 Nov 2017

Turkle S (2015) Reclaiming conversation: the power of talk in a digital age. Penguin Random House, New York City

Varian HR (2013) Beyond big data. http://people.ischool.berkeley. edu/ hal/Papers/2013/BeyondBigDataPaperFINAL.pdf. Accessed 13 Nov 2017

Vincent J (2017) Giving robots 'personhood' is actually about making corporations accountable. Verge, Thursday 19 January. https:// www.theverge.com/2017/1/19/14322334/robot-electronic-persons-eu-report-liability-civil-suits. Accessed 13 Nov 2017

Wilks Y (2006) Artificial companions as a new kind of interface to the future internet. OII Research Report 13. https://doi.org/10.2139/ ssrn.1308528. Accessed 13 Nov 2017

Zuboff S (2015) Big other: surveillance capitalism and the prospects of an information civilization. J Inf Technol 30:75-89 